\title{
Regional Assessment of Population and Warming of a Tropical Country, Nigeria, from 2006 to 2036
}

\author{
Nwaerema Peace* ${ }^{*}$ Edokpa David \\ Department of Geography and Environmental Management, University of Port Harcourt, Choba, Nigeria
}

Corresponding Author Email: pnwaerema486@gmail.com

https://doi.org/10.18280/eesrj.060101

Received: 2 January 2019

Accepted: 4 March 2019

\section{Keywords:}

heat island, Nigeria, population, population density, states, regional population

\begin{abstract}
This research assessed population variability and prediction of heat island in a tropical country, Nigeria, from 2006 to 2036. Data for heat island were generated from records of the National Population Commission (NPC) using the population mathematical model. With national population growth rate of $2.67 \%$, Nigeria recorded average heat island of $6.1{ }^{\circ} \mathrm{C}$ with variation of $0.1{ }^{\circ} \mathrm{C}$ per decade indicating that heat island is on the increase. The North Central region had heat island variation of $0.3{ }^{\circ} \mathrm{C}$ per decade; North East had heat island of $0.1{ }^{\circ} \mathrm{C}$, North West $0.1{ }^{\circ} \mathrm{C}$, South East $0.1{ }^{\circ} \mathrm{C}$, South-South $0.2{ }^{\circ} \mathrm{C}$ and South West $0.2{ }^{\circ} \mathrm{C}$ respectively. The six regions had heat island of $5.4{ }^{\circ} \mathrm{C}$ to $5.6{ }^{\circ} \mathrm{C}$ greater than $0.5-2.5{ }^{\circ} \mathrm{C}$ recommended standard indicating that human comfort has been compromised in Nigeria. Results show that heat island across the regions differ significantly. Also, population density is not associate variable that causes heat island in the regional landmass of Nigeria. It therefore recommends national planners and development practitioners to implement population control and tree planting strategies. The research has contributed to the interactive roles of population and landmass in heat island effects. Therefore, a control of population growth lowers the effect of heat island in Nigeria.
\end{abstract}

\section{INTRODUCTION}

In Nigeria there is constant alteration of the environment due to population growth and more anthropogenic activities. These activities have raised the temperature of living areas above those of undeveloped plots resulting to the concept of Heat Island (HI). Heat island occurs when the temperature of manmade developed surfaces is greater than those of the extended undeveloped fringes [1]. Man's economic activities and pavement materials keep generating heat that results to some level of discomfort in the environment. The population of Nigeria has grown to $197,375,677$ persons in recent time with over $50 \%$ of the population moving to urban areas [2]. It is therefore anticipated that heat island is growing with greater magnitude across the various regions of Nigeria which cut across different climatic belts. Today, the world population has grown over 8 billion persons with $60 \%$ that will occupy the urban centers in year 2030 and will increase to $70 \%$ in 2050 as well as estimated 50 persons per square kilometer if continental and island areas are included [3].

In the last two decades, the global mean temperature has increased by $0.1^{\circ} \mathrm{C}$ per decade, with 2005 being the warmest year on record $[4,5]$. Due to the geographical position of Africa, an increase of $2^{\circ} \mathrm{C}$ heat will put 50 percent of the continent's population at health risk due to the considerably limited adaptive capacity and widespread poverty [6]. In a study on African, it is estimated that $30 \mathrm{C}$ rise in global warming could increase five times the heat waves of the continent with the attendant health impact [7]. Increase in population and heat island will result to heat waves, raised cost of environmental cooling, high pollution reaction, alteration of water bodies, health hazard and eventual death especially children and the old people [8]. When the environment is in its natural condition without modification, air temperature will be stable and operating at a human comfort threshold with little or no heat island effect.

Heat island is accelerated by many factors such as rise in manmade fabrics, clearance of tree canopies, emission of green greenhouse, erection of structures, material albedo, material thermal performance, size of developed land surface and all human economic activities [9]. With land mass of $923,768 \mathrm{~km}^{2}$ of Nigeria, population and urbanization are increasing the developed surface areas of different regions of the country thereby producing more heat island effects [10]. Heat island has been greatly studied in rural and urban scale but much attention has not been given to heat island at larger national and continental scales especial the tropical countries of Africa where the natural solar energy is high. The scope of this study is to assess the dynamic interaction of population and heat island at regional levels and their pattern. It systematically analyzes the operations of climatic conditions in the distribution of regional population and heat island for 30 years in Nigeria. Thus, understanding special effects of population and regional landmass on heat island phenomenon will aid national planners to manage environmental warming with minimum or no heat island consequences.

\section{DESCRIPTION OF STUDY AREA}

Nigeria is located within $3^{\circ}$ and $14^{\circ}$ East Longitude and $4^{\circ}$ and $14^{\circ}$ North Latitude. The east to west distance of Nigeria is approximately 767 kilometers; while the distance from the north to the south is about 1,605 kilometers. The country is founded in the east and north hemispheres of West Africa. It has borders with Benin in the west, Niger in the north, Chad 
in the north-eastern part, Cameroon in the core east and the Atlantic Ocean in the southern part Figure 1. Nigeria has total area coverage of $923,768 \mathrm{~km}^{2}$ with land area of $910,768 \mathrm{~km}^{2}$ and $13,000 \mathrm{~km}^{2}$ water cover $[2,10]$. The country is separated by two major rivers, Niger and Benue aiding exchange of land and sea breezes in the interior land features. Nigeria is divided into six (6) regions (Figure 4) made up of North-East, North-West, Middle Belt, South East, South-West and SouthSouth, respectively. The country has three (3) wind flow classification aiding heat distribution across the regions (Figure 5).
Nigeria is the largest country in Africa ranking the eight most populated in the world. With $186,053,386$ persons, the population density is $204.28 / \mathrm{km}^{2}$ indicating the number of persons modifying biophysical features of the environment per kilometer square. With reduction in birth rate, the country population is projected to grow to 239 million persons in 2025 and by 2050 it will attain 440 million persons which will make it the $4^{\text {th }}$ most populous country in the world [11, 12]. Nigeria urban population is rising above the rural population [12].

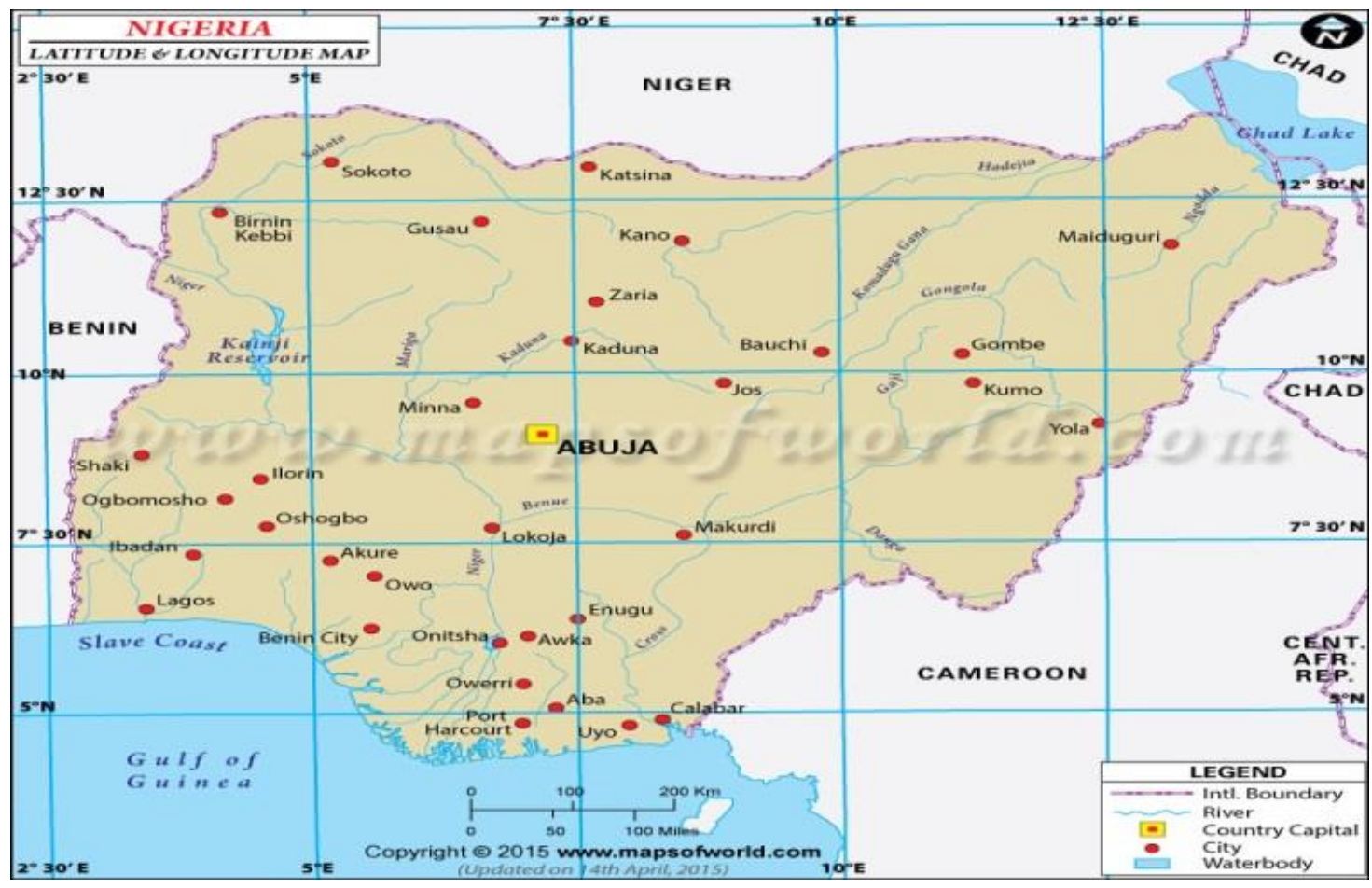

Figure 1. Nigeria location map

The economy of Nigeria is dependent on oil and gas with about $90 \%$ of export earnings. It is the largest crude oil producer in Africa and the $8^{\text {th }}$ in the world exporting 1.591.65 million barrels per day taking place in the southern region of the country. In agriculture, Nigeria employs $65 \%$ of the population. Recently, practice of farming has dropped due to over-dependent on oil and intense migration to the cities. Livestock is produced in the northern part of the country. Fish is produced at annual rate of 250 thousand tons. Approximately $90 \%$ of wood resources are used for cooking [13]. The general economic activities and population growth rate show greater impact of deforestation and anthropogenic heat release in Nigeria.

In the southern part of Nigeria, mean maximum temperature is about $32{ }^{\circ} \mathrm{C}$ and $41^{\circ} \mathrm{C}$ in the north. The mean minimum temperature in the south is $21{ }^{\circ} \mathrm{C}$ and $13{ }^{\circ} \mathrm{C}$ in the north. Nigeria recorded mean temperature of $27{ }^{\circ} \mathrm{C}$ without any altitudinal modifications and global warming [1]. The rainfall is at $2,500 \mathrm{~mm}$ in the south and low with $400 \mathrm{~mm}$ in the extreme northern parts like Maiduguri [9]. Nigeria has two main tropical climates of wet and dry seasons. In the south, wet season occurs from March to November and in the north from May to October. The remaining months are occupied by dry season [9].
Nigeria Climate varies from humid, sub-humid, semi-arid and arid regions which give rise to sub-seasons of long wet season, short dry season, short wet season and long dry season, respectively (Figure 2). It can be classified according to vegetal cover of Guinea, Sudan and Sahel, Mangrove as well as Rain Forests (Figure 3). Rainfall occurrence is higher in the south than the north making the southern part have more water bodies necessary for air temperature and moisture moderation.

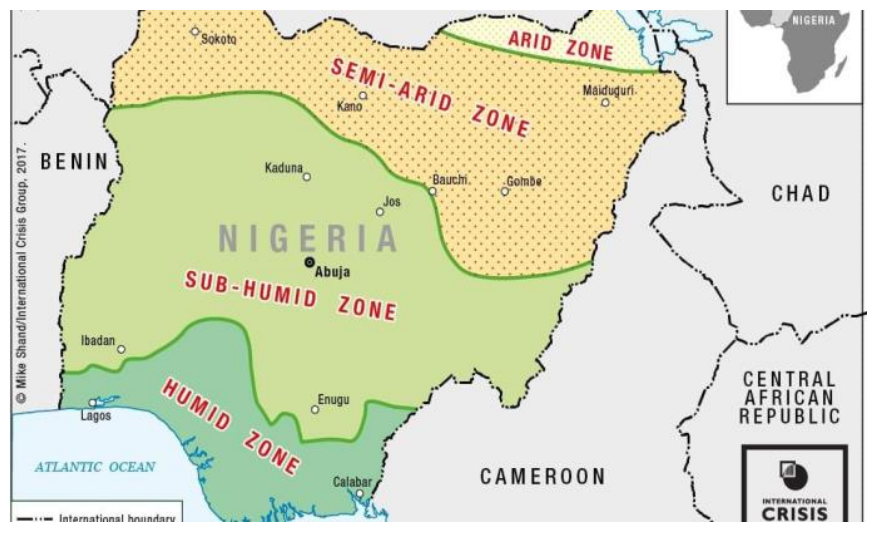

Figure 2. Nigeria climate regions 


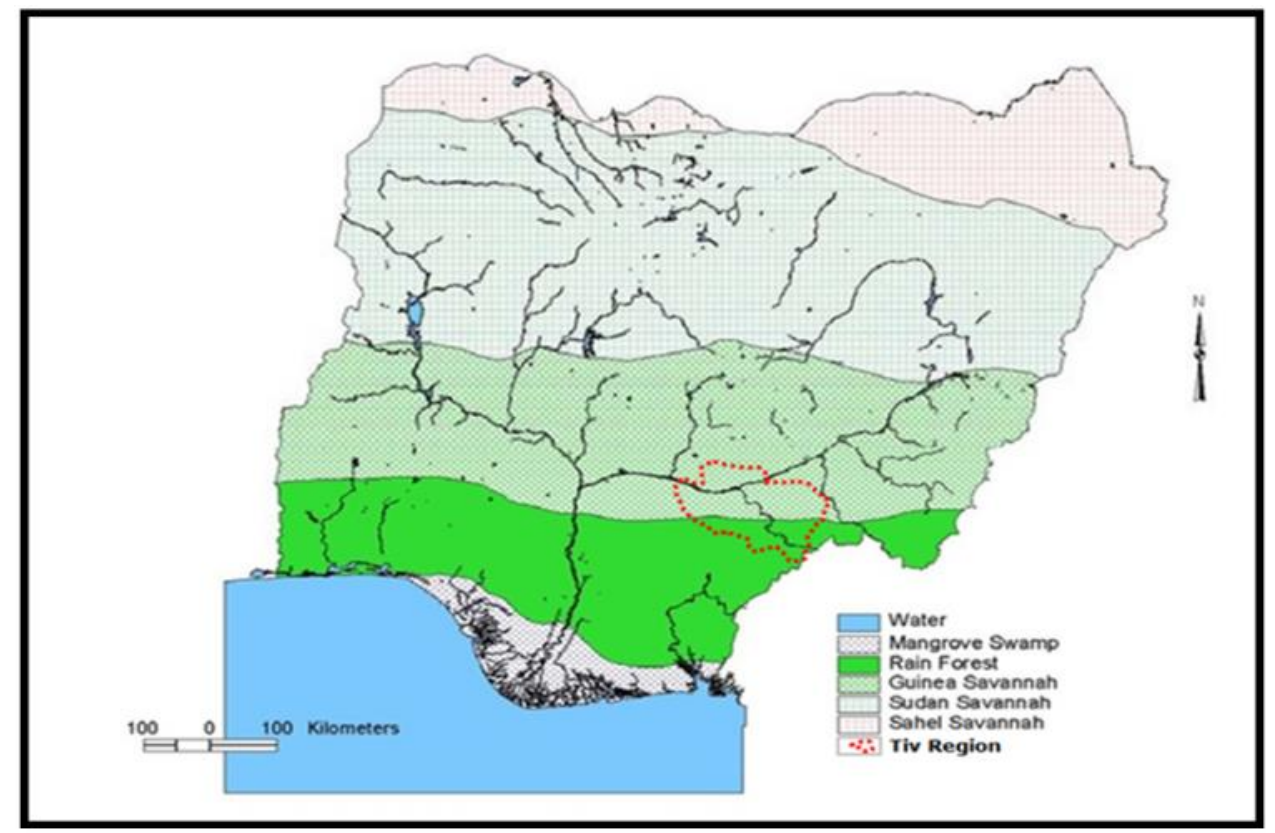

Figure 3. Nigeria climatic belts

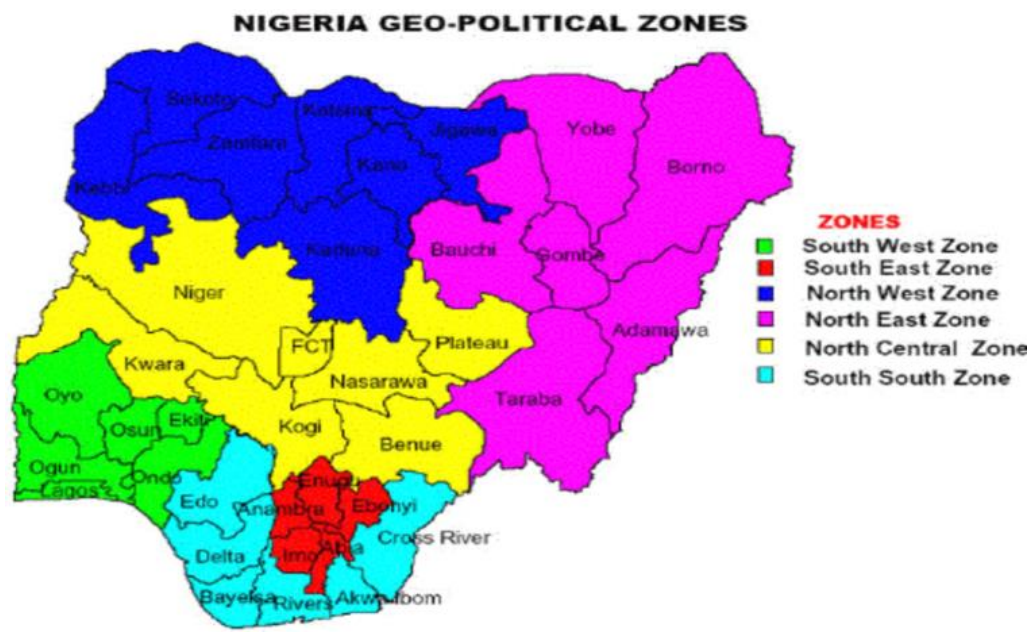

Figure 4. Nigeria six (6) regions

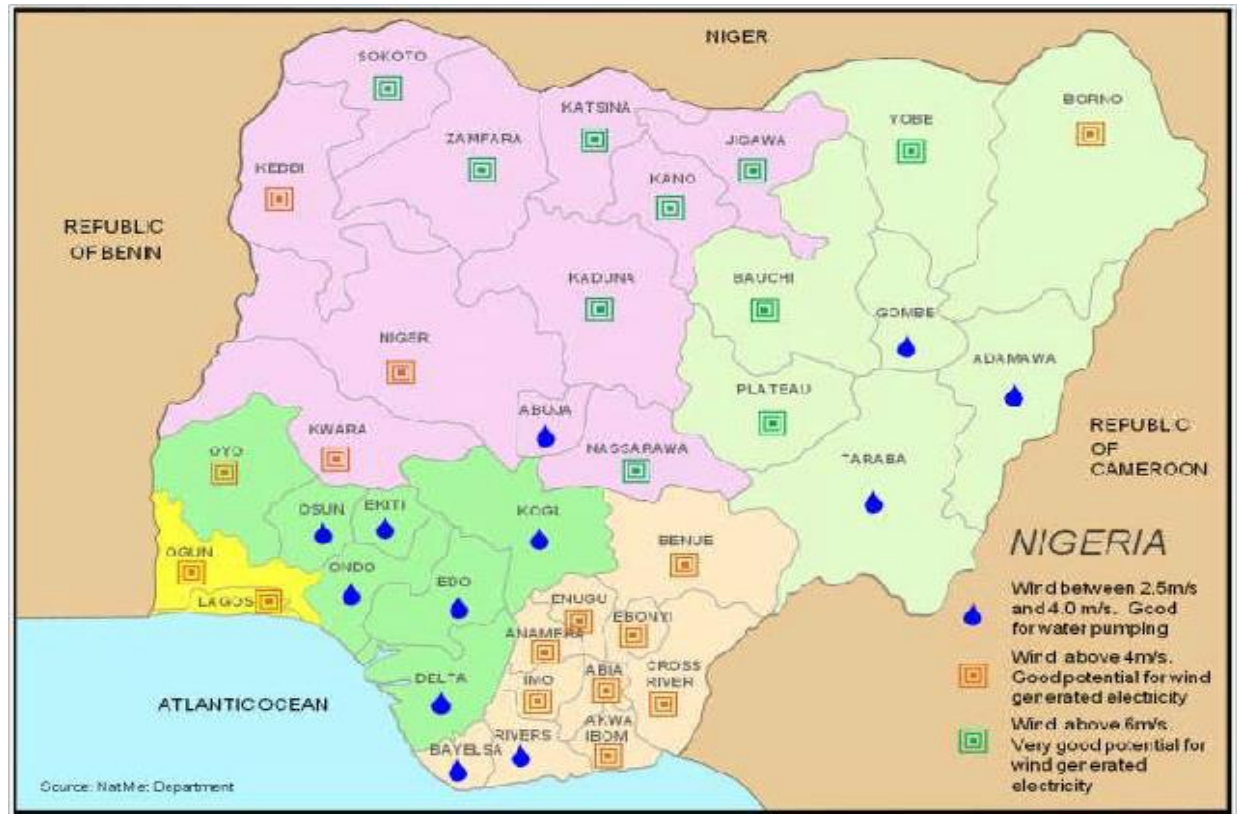

Figure 5. Nigeria states and wind flow systems 


\section{MATERIALS AND METHODS}

This assessment is based on secondary data. For population data, they were collected from records of National Population Commission (NPC) 2006 and projected up to 2036 with growth rate of $2.67 \%$ across the states. Data for heat island were generated from population records using the population mathematical model of [14]. The development of heat island is tied to population of a place which can be used as prediction model for generalization in climatic modeling, urban planning and weather forecasting. The heat island in Degree Celsius $\left({ }^{\circ} \mathrm{C}\right)$ increases with population according to the formula:

\section{Heat Island $=0.73 \log _{10}$ Pop}

where: Pop denotes population.

Adopting the formula, Oke and Hoyt were of the opinion that a settlement with 10 persons has heat island of $1.46{ }^{\circ} \mathrm{C}$ and settlement with 1000 persons has a heat island of $2.2{ }^{\circ} \mathrm{C}$ as well as a large city with a million people has heat island of $4.4^{\circ} \mathrm{C}[14,15]$. The population mathematical model was used to generate data for predicting heat island in the six regions of Nigeria. Descriptive statistics such as mean and range were used for the analysis. Analysis of Variance (ANOVA) was used to establish whether heat island vary across the regions. Pearson product moment correlation coefficient was applied to know whether there is association between heat bias and population density in the six regions.

\section{RESULTS AND DISCUSSION}

Nigeria is divided into six regions of identical geographic characteristics of 36 states namely: North Central, North East, North West, South East, South-South and South West respectively (Figure 4). The North Central seven states are Benue, Kogi, Kwara, Nasarawa, Niger, Plateau and Federal Capital Territory. The six states in the North East Region are Adamawa, Bauchi, Borno, Gombe and Yobe. The seven
North West states are Jigawa, Kaduna, Kano, Katsina, Kebi, Sokoto and Zamfara. For the South East, the five states are Abia, Anambra, Ebonyi, Enugu and Imo. South-South six states are AkwaIbom, Bayelsa, Cross River, Delta, Edio and Rivers. The six South West States are Ekiti, Lagos, Ogun, Ondo, Osun and Oyo.

Nigeria has total projected population at $2.67 \%$ growth rate from 2006 to 2036 . In 2006, the population recorded 140,431, 790 persons, 177,529, 710 persons in 2016, and $225,109,865$ persons in 2026 as well as $285,600,414$ persons in 2036 (Table 1). Average population density of Nigeria from 2006 to 2036 varied with $263.24 / \mathrm{Km}^{2}$ with the lowest population density of $254.53 / \mathrm{Km}^{2}$ in 2006 and highest of $517.86 / \mathrm{Km}^{2}$ in 2036 (Table 1). The heat island of Nigeria at 6 ${ }^{\circ} \mathrm{C}$ was constant from 2006 to 2016 and a shift from $6.1{ }^{\circ} \mathrm{C}$ to $6.2{ }^{\circ} \mathrm{C}$ with variation of $0.1{ }^{\circ} \mathrm{C}$ from 2026 to 2036 (Table 1).

The North Central of Nigeria is the fourth most populated region with projection of $24,923,882$ persons in 2006, $24,923,882$ persons in 2016, 32,699,660 persons in 2026 and $41,430,465$ persons in 2036 . It has population growth range of 21,060,509 between 2006 and 2036 (Table 1 and Figure 6). The region has land mass of $226,666 \mathrm{Km}^{2}$ and population density of $89.87 / \mathrm{Km}^{2}$ in $2006,110 / \mathrm{Km}^{2} 2016,144.26 / \mathrm{Km}^{2}$ in 2026 and $182.84 \mathrm{Km}^{2}$ in 2036 respectively. The population density varies with $93 / \mathrm{Km}^{2}$ between 2006 and 2036 making it the fifth density region in Nigeria. Decadal heat island variations of North Central region are $5.3{ }^{\circ} \mathrm{C}, 5.4{ }^{\circ} \mathrm{C}, 5.5{ }^{\circ} \mathrm{C}$, $5.6{ }^{\circ} \mathrm{C}$ with $0.1{ }^{\circ} \mathrm{C}$ between 2006 and 2030 respectively (Table 2 and Figure 8) indicating that it has exceeded the human comfort threshold of 0.5-2.5 ${ }^{\circ} \mathrm{C}$ [16-17]. North Central region is located in the Sub-humid, Guinea and Sudan Savanna belts with wind velocity of $4-6 \mathrm{~m} / \mathrm{s}$ within the lower troposphere (Figures 2, 3 and 4). The location of North Central region in these climatic belts gives it relative advantage of quicker evacuation of generated heat island. But the air temperature will continuously be raised by insolation due to poor vegetal cover, lack of water bodies and terrain modification by man's economic activities.

Table 1. Population of the six regions of Nigeria

\begin{tabular}{|c|c|c|c|c|}
\hline Region/Year & 2006 & 2016 & 2026 & 2036 \\
\hline $\begin{array}{c}\text { North } \\
\text { Central }\end{array}$ & $20,369,956$ & $24,923,882$ & $32,699,660$ & $41,430,465$ \\
\hline North East & $18,984,299$ & $24,053,103$ & $30,475,278$ & $38,612,174$ \\
\hline North West & $35,915,467$ & $45,510,234$ & $57,356,622$ & $73,057,070$ \\
\hline South East & $16,395,555$ & $20,773,166$ & $26,319,600$ & $33,346,931$ \\
\hline South-South & $21,044,081$ & $27,147,006$ & $33,781,824$ & $42,801,568$ \\
\hline South West & $27,722,432$ & $35,122,319$ & $44,476,881$ & $56,352,206$ \\
\hline Total & $140,431,790$ & $177,529,710$ & $225,109.865$ & $285,600,414$ \\
\hline Heat Island & 6 & 6 & 6.1 & 6.2 \\
\hline
\end{tabular}

The North East of Nigeria is the fifth most populated region having projection of $18,984,299$ persons in 2006 , $24,053,103$ persons in 2016, 30,475,278 persons in 2026 and $38,612,174$ persons in 2036 respectively. It has population growth range of 19,627,876 between 2006 and 2036 (Table 1 and Figure 6). The region has land mass of 28,031,213 $\mathrm{Km}^{2}$ and population density of $67.6 / \mathrm{Km}^{2}$ in $2006,85.78 / \mathrm{Km}^{2} 2016$, $108.68 / \mathrm{Km}^{2}$ in 2026 and $137.7 / \mathrm{Km}^{2}$ in 2036 , respectively. The population density varies with $70.1 / \mathrm{Km}^{2}$ between 2006 and 2036 making it the least human density region. Decadal heat island variations of North East region are $5.3{ }^{\circ} \mathrm{C}, 5.3{ }^{\circ} \mathrm{C}$, $5.5{ }^{\circ} \mathrm{C}, \quad 5.5{ }^{\circ} \mathrm{C}$ with $0.2{ }^{\circ} \mathrm{C}$ between 2016 and 2026 accordingly (Table 2 and Figure 8) indicating that it has exceeded the human comfort threshold. The North East Region is located in a mixed geographic region of Sahel, Sudan, Guinea, Sub-humid, Semi-arid and Arid regions. The southern part of the region has wind velocity of $2.5-4 \mathrm{~m} / \mathrm{s}$ and in the other segment sit maintains wind speed above $4 \mathrm{~m} / \mathrm{s}$ up 
to $6 \mathrm{~m} / \mathrm{s}$ in the lower troposphere. This is an indication that the region will be influenced by the high wind speed to moderate heat island. The poor vegetal, water and high solar energy of the region will increase air temperature above the acceptable $27^{\circ} \mathrm{C}$ human comfort threshold.

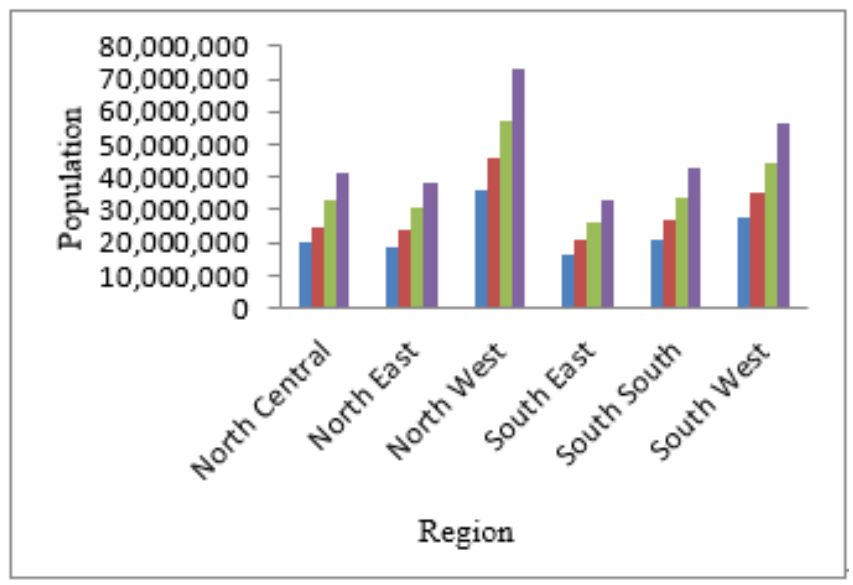

Figure 6. Population distribution of the six regions

Table 2. Population density of the six regions

\begin{tabular}{cccccc}
\hline Region & $\mathbf{2 0 0 6}$ & $\mathbf{2 0 1 6}$ & $\mathbf{2 0 2 6}$ & $\mathbf{2 0 3 6}$ & Land Mass \\
\hline $\begin{array}{c}\text { North } \\
\text { Central }\end{array}$ & 89.87 & 110 & 144.26 & 182.84 & $29,855,990$ \\
$\begin{array}{c}\text { North } \\
\text { East }\end{array}$ & 67.6 & 85.78 & 108.68 & 137.7 & $28,031,213$ \\
$\begin{array}{c}\text { North } \\
\text { West }\end{array}$ & 191.3 & 242.41 & 305.51 & 389.14 & $217,263,275$ \\
$\begin{array}{c}\text { South } \\
\text { East }\end{array}$ & 569.55 & 721.62 & 914.29 & $1,158.4$ & $24,208,813$ \\
$\begin{array}{c}\text { South- } \\
\text { South } \\
\text { South }\end{array}$ & 248.7 & 320.83 & 399.24 & 505.83 & $31,193,619$ \\
West & 360.72 & 457.01 & 578.73 & 733.27 & $40,918,459$ \\
\hline $\begin{array}{c}\text { Mean } \\
\text { Pop. }\end{array}$ & 254.62 & 323 & 408.45 & 517.86 & \\
Density & & & & & \\
\hline
\end{tabular}

The North West of Nigeria is the most populated region with projection of $35,915,467,45,510,234,57,356,622$ and $73,057,070$ persons in 2006, 2016, 2026 and 2036, respectively. It has population growth range of $37,141,603$ between 2006 and 2036 (Table 1 and Figure 6). The region has land mass of $217,263,275 \mathrm{Km}^{2}$ and population density of $191.3 / \mathrm{Km}^{2}$ in $2006,242.41 / \mathrm{Km}^{2} 2016,305.51 / \mathrm{Km}^{2}$ in 2026 and $389.14 / \mathrm{Km}^{2}$ in 2036 , respectively. The population density varies with $191.84 / \mathrm{Km}^{2}$ between 2006 and 2036 making it forth of the population density region. Decadal heat island variations of North West region are $5.5^{\circ} \mathrm{C}, 5.6^{\circ} \mathrm{C}, 5.7$ ${ }^{\circ} \mathrm{C}, 5.7{ }^{\circ} \mathrm{C}$ and variation of $0.1{ }^{\circ} \mathrm{C}$ between 2016 and 2026, respectively (Table 2 and Figure 8) indicating that it has exceeded the human comfort threshold. It is located in a mixed geographic region of Sahel and Sudan Savanna. The air moisture type is the Sub-humid and Semi-arid regions. It has wind velocity of $4 \mathrm{~m} / \mathrm{s}$ and above $6 \mathrm{~m} / \mathrm{s}$ in the lower troposphere. This is an indication that the region will be influenced by high wind speed capable moderating the heat island and high temperature effects due to low vegetal cover, poor water bodies and high intensity of solar energy of the region. It is important that the North West region operate with temperature of $27{ }^{\circ} \mathrm{C}$ human comfort which is not common in the arid and low humid geographic regions.

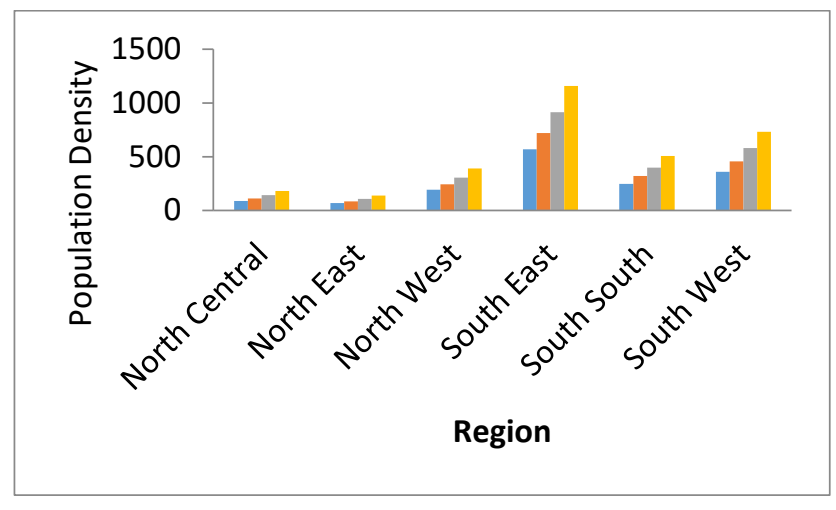

Figure 7. Population density distribution of the six regions

Table 3. Heat island of the six regions of Nigeria

\begin{tabular}{cccccc}
\hline Region/Year & $\mathbf{2 0 0 6}$ & $\mathbf{2 0 1 6}$ & $\mathbf{2 0 2 6}$ & $\mathbf{2 0 3 6}$ & Mean \\
\hline North Central & 5.3 & 5.4 & 5.5 & 5.6 & 5.5 \\
North East & 5.3 & 5.3 & 5.5 & 5.5 & 5.4 \\
North West & 5.5 & 5.6 & 5.7 & 5.7 & 5.6 \\
South East & 5.3 & 5.3 & 5.4 & 5.5 & 5.4 \\
South-South & 5.3 & 5.4 & 5.5 & 5.6 & 5.5 \\
South West & 5.4 & 5.5 & 5.6 & 5.7 & 5.6 \\
Mean & 5.4 & 5.4 & 5.5 & 5.6 & 5.5 \\
Decadal & 0 & 0 & 0.1 & 0.1 & 0.1 \\
Growth & 0.2 & 0.3 & 0.3 & 0.2 & \\
\hline Yearly Range & 0.2 & & & &
\end{tabular}

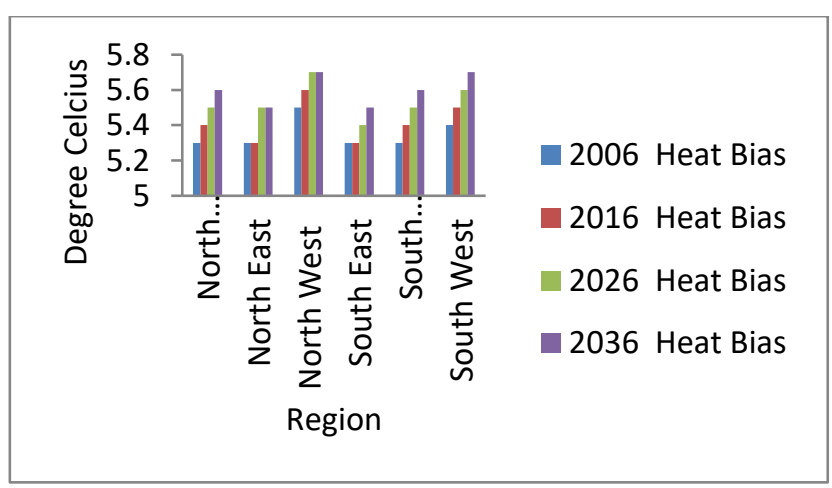

Figure 8. Heat island distribution of the regions of Nigeria

South East is the least populated region with 16,395,555, $20,773,166,26,319,600$ and $33,346,931$ persons in 2006, 2016, 2026 and 2036, respectively. It has population range of 16,951,376 between 2006 and 2036 (Table 1 and Figure 6). The region has land mass of $24,208,813 \mathrm{Km}^{2}$ and population density of $569.55 / \mathrm{Km}^{2}$ in $2006,721.62 / \mathrm{Km}^{2} 2016$, $914.29 / \mathrm{Km}^{2}$ in 2026 and $1,158.4 / \mathrm{Km}^{2}$ in 2036 respectively. The population density varies with $588.85 / \mathrm{Km}^{2}$ between 2006 and 2036; which makes the region the highest density region. Decadal heat island variation of South East region is $5.3^{\circ} \mathrm{C}$, $5.3{ }^{\circ} \mathrm{C}, 5.4{ }^{\circ} \mathrm{C}, 5.5{ }^{\circ} \mathrm{C}$ and variation of $0.1{ }^{\circ} \mathrm{C}$ between 2026 and 2036, respectively (Table 2 and Figure 8) indicating that it has exceeded the human comfort threshold. The region is located in the mangrove rainforest of southern Nigeria covered with vegetation and water bodies as well as wind velocity above $4 \mathrm{~m} / \mathrm{s}$ in the lower troposphere which aid the moderation of heat island generation of the region. 
South-South region is the third most populated with projection of $21,044,081,27,147,006,33,781,824$ and 42,801,568 persons in 2006, 2016, 2026 and 2036, respectively. Population of the region is growing with a range of 21,757,487 between 2006 and 2036 (Table 1 and Figure 6). The region has land mass of $31,193,619 \mathrm{Km}^{2}$ and population density of $248.7 / \mathrm{Km}^{2}$ in $2006,320.83 / \mathrm{Km}^{2}$ in 2016 , $399.24 / \mathrm{Km}^{2}$ in 2026 and $505.83 / \mathrm{Km}^{2}$ in 2036 respectively. The population density varies with $257.13 / \mathrm{Km}^{2}$ between 2006 and 2036 making it the third highest human density region. Decadal heat island of South-South region are $5.3{ }^{\circ} \mathrm{C}, 5.4{ }^{\circ} \mathrm{C}$, $5.5^{\circ} \mathrm{C}, 5.6^{\circ} \mathrm{C}$ and variation of $0.1{ }^{\circ} \mathrm{C}$ (Table 2 and Figure 8) indicating that it has exceeded the human comfort threshold. It is another region that is located in the southern part of Nigeria covered with mangrove rainforest and water bodies as well as wind velocity of $2.5 \mathrm{~m} / \mathrm{s}$ and below $6 \mathrm{~m} / \mathrm{s}$ in the lower troposphere. The South-South region is nearest to the Atlantic Ocean which transfers moisture inland thereby keeping the air temperature moderately cool depending on the season and period of the year.

South West region is the second most populated region with projected population of $27,722,432,35,122,319$, 44,476,881 and 56,352,206 persons in 2006, 2016, 2026 and 2036 , respectively. Population of the region improved with a range of 28,629,774 between 2006 and 2036 (Table 1 and Figure 6). The region has land mass of 40,918,459 $\mathrm{Km}^{2}$ and population density of $360.72 / \mathrm{Km}^{2}$ in $2006,457.01 / \mathrm{Km}^{2}$ in 2016, $578.73 / \mathrm{Km}^{2}$ in 2026 and $733.27 / \mathrm{Km}^{2}$ in 2036 , respectively. The population density varies with $372.55 / \mathrm{Km}^{2}$ between 2006 and 2036 making it the second human density region. Decadal heat island variations of South-West region are $5.4{ }^{\circ} \mathrm{C}, 5.5{ }^{\circ} \mathrm{C}, 5.6{ }^{\circ} \mathrm{C}, 5.7{ }^{\circ} \mathrm{C}$ and variation of $0.1{ }^{\circ} \mathrm{C}$ (Table 2 and Figure 8) indicating that it has exceeded the human comfort threshold. South West region is located in the sub-humid, humid, rainforest as well as the Guinea savanna of Nigeria. It recorded wind velocity below $4 \mathrm{~m} / \mathrm{s}$ making the region trap heat island beyond the comfort threshold. The Lagos segment of the region is close to the Atlantic Ocean which transfers moisture hinterland.

The North East and South East regions had identical mean heat island of $5.4{ }^{\circ} \mathrm{C}$; North Central and South-South acquired similar mean heat island of $5.5^{\circ} \mathrm{C}$. The North West and South West had highest mean heat island of $5.6{ }^{\circ} \mathrm{C}$ respectively (Table 3). Generally, regions in the northern part of Nigeria had higher population density, larger land mass and low population density as well as high wind velocity capable of evacuating generated heat from the ground surface. The northern geo-political regions had high influence of solar energy that raised the air temperature aiding the propagation of heat island effect. On the other hand, regions in the south had high population density with limited land mass due the restriction of mangrove rainforests and unfavorable terrain of water bodies and swamps. The southern region had weak wind speed that could aid heat island propagation and trapping in the ambient air thereby increasing the air temperature that could result to accelerated power demand, air pollution reaction, poor water quality, heat stress and eventual death of people.

The first hypothesis (Ho) stated that there is no significant difference in heat island across the regions (2006 to 2036). The Analysis of Variance (ANOVA) test was applied (Table 4 ). The ANOVA result has P-value of $1.58 \mathrm{E}-07$ and $5.53 \mathrm{E}$ 09 greater than 0.05 Significant Level. This indicates that heat island across the regions differ significantly. This is the same with the earlier view that North Central, North East, North West, South East, South-South and South West had varied heat island of $5.5{ }^{\circ} \mathrm{C}, 5.4{ }^{\circ} \mathrm{C}, 5.6{ }^{\circ} \mathrm{C}, 5.4{ }^{\circ} \mathrm{C}, 5.5{ }^{\circ} \mathrm{C}$ and $5.6{ }^{\circ} \mathrm{C}$, respectively.

The second hypothesis (Ho) stated that there is no relationship between heat Island and population density across the regions of Nigeria. The Person Product-Moment Correlation Coefficient $\left(\mathrm{r}^{2}\right)$ was applied. The result shows no correlation value of 0.04 . This indicates that heat island and population density are not associate variables in the regional landmass of Nigeria. This is in tandem with the earlier view that South East region which has the highest density of $569.55 / \mathrm{Km}^{2}$ in $2006,721.52 \mathrm{Km}^{2}$ in $2016,914.29 \mathrm{Km}^{2}$ in 2026 and $1,158 / \mathrm{Km}^{2}$ in 2036 had heat island of $5.4{ }^{\circ} \mathrm{C}$ lesser than that of North Central $5.5{ }^{\circ} \mathrm{C}$, South West $5.6{ }^{0} \mathrm{C}$ and North West $5.6{ }^{\circ} \mathrm{C}$ with lesser population density.

Table 4. ANOVA test explaining the difference in heat island across the regions

\begin{tabular}{ccccccc}
\hline $\begin{array}{c}\text { Source of } \\
\text { Variation }\end{array}$ & SS & df & MS & F & P-value & F-critical \\
\hline Rows & 0.18 & 5 & 0.036 & 32.4 & $1.58 \mathrm{E}-07$ & 2.901295 \\
Columns & 0.228333 & 3 & 0.076111 & 68.5 & $5.53 \mathrm{E}-09$ & 3.287382 \\
Error & 0.016667 & 15 & 0.001111 & & & \\
\hline Total & 0.425 & 23 & & & & \\
\hline
\end{tabular}

\section{CONCLUSION}

This research analyzed regional population variation and prediction of heat island in a tropical country, Nigeria. Data for heat island were generated from records of the National Population Commission (NPC) using the population mathematical model. With national population growth rate of $2.67 \%$, Nigeria recorded average heat island of $6.1{ }^{\circ} \mathrm{C}$ with current population of over177, 529,319 indicating that it has exceeded the $0.5-2.5{ }^{\circ} \mathrm{C}$ standard comfort threshold. The North Central region had population growth of $21,060,509$ from 2006 to 2036 and a shift of heat island from $5.3{ }^{\circ} \mathrm{C}$ to $5.6{ }^{\circ} \mathrm{C}$. North East had population increase of 19,627, 826 and variation of heat island from $5.3{ }^{\circ} \mathrm{C}$ to $5.4{ }^{\circ} \mathrm{C}$ during the period; North West region $37,141,603$ persons added population and heat island rise from $5.5^{\circ} \mathrm{C}$ to $5.6^{\circ} \mathrm{C}$. South East had additional population of 16,951,376 and heat island increment from $5.3{ }^{\circ} \mathrm{C}$ to $5.4{ }^{\circ} \mathrm{C}$; South-South region had population increase of 21757,487 and heat island rise from $5.3{ }^{\circ} \mathrm{C}$ to $5.5{ }^{\circ} \mathrm{C}$. Also, South West region added 28,629,774 persons within the thirty years and heat island shift from 5.4 ${ }^{\circ} \mathrm{C}$ to $5.6{ }^{\circ} \mathrm{C}$, respectively. The analytical results show that heat island across the regions differ significantly. Also, that heat island and population density are not associate variables in the regional landmass of Nigeria. Therefore, National planners and development practitioners should manage land 
space with utmost attention by integrating environment friendly materials such as green roofs and tree planting in cities in order to curve the menace of heat island in Nigeria.

\section{REFERENCES}

[1] Nwaerema P, Nwagbara MO. (2018). Spatial and temporal variability of weekday urban heat island in port Harcourt and environs. The International Journal of Science and Technoledge 6(3): 127-136.

[2] National Population Commission (2006). https://www.google.com.ng/?gfe_rd=cr\&ei=Kqn2WM OOBrGn8weazqO4CA\&gws_rd=ssl\#q=2006+national+ population+census, accesses on Jan. 14, 2018.

[3] World Health Organization (WHO). Urban population growth (2013). http://www.who.int/gho/urban_health/situation_trends/u rban_population_growth_text/en/, accessed on July 13, 2018.

[4] National Aeronautics and Space Administration (NASA). (2005). National Aeronautics and Space Administration, warmest year in over a century. http://www.nasa.gov/vision/earth/environment/ 2005warmest.html. Accessed on April 27, 2018.

[5] National Aeronautics and Space Administration (NASA). (2009). National Aeronautics and Space Administration.

http://climate.jpl.nasa.gov/keyindicators, accessed on April 27, 2018.

[6] UN Environment (2018). Responding to Climate Change.https://www.unenvironment.org/regions/africa/r egional-initiatives/responding-climate-change, accessed on April 4, 2018.

[7] Carbornbrief (2018). Mapped: African heat waves could increase five-fold with $3{ }^{\circ} \mathrm{C}$ of global warming. https://www.carbonbrief.org/mapped-africanheatwaves-could-increase-five-fold-with-3c-of-globalwarming, accessed on July 14, 2018.

[8] Wong K, Paddon A, Jimenez A. (2013). Review of world urban heat islands: Many linked to increased mortality. Journal of Energy Resources Technology 135(2): 02101. https://doi.org/10.1115/1.4023176
[9] Nwaerema P, Weli VE. (2018). Urban warming in port Harcourt metropolis and environs. Journal of Geography, Environment and Earth Science International 14(4): 1-12. http://doi.org/10.9734/JGEESI/2018/4112

[10] Annual Abstract of Statistics (2012). National Bureau of Statistics. Federal Republic of Nigeria. https://www.nigerianstat.gov.ng. Accessed on March 11, 2018.

[11] National Population Commission (2006). https://www.google.com.ng/?gfe_rd=cr\&ei=Kqn2WM OOBrGn8weazqO4CA\&gws_rd=ssl\#q=2006+national+ population+census. Accessed on Jan. 1, 2018.

[12] United Nations. World Urbanization Prospects (2009). The Revision: Population Division of the Department of Economic and Social Affairs of the United Nations Secretariat, New York: United Nations; 2009. http://esa.un.org/wup2009/unup/index.asp. Accessed on March 29, 2018.

[13] Nigeria's Information (2018). https://www.worldatlas.com/webimage/countrys/africa/ nigeria/nglatlog.htm.Accessed on Feb. 8, 2018.

[14] Oke TR. (1979). Review of Urban Climatology 19731979. World Meteorological Organization\Technical Note: 169, World Meteorological Organization, Geneva, 100 . https://library.wmo.int/doc_num.php?explnum_id=880, accessed on Aug. 23, 2018.

[15] Hoyt D. (2006). Urban Heat Island and land use changes. htpp://www.warwickhughes.com/hoyt/uhi.htm, accessed on April 11, 2018.

[16] Lemonsua V, Viguieb M, Daniela VM. (2015). Vulnerability to heat waves: Impact of urban expansion scenarios on urban heat island and heat stress in Paris (France). https://doi.org/10.1016/j.uclim.2015.10.007

[17] Steeneveld J, Koopmans S, Heusinkveld BG, van Hove LWA, Holtslag AAM. (2011). Quantifying urban heat island effects and human comfort for cities of variable size and urban morphology in the Netherlands. JGR: Atmospheres 116(D20) http://dx.doi.org/10.1016/j.landurbplan.2013.09.00 